\title{
Carbon Storage in Cocoa Growing Systems Across Different Agroecological Zones in Ghana
}

\author{
John Tennyson Afele ${ }^{1 *}$, Evans Dawoe ${ }^{1)}$, Akwasi Adutwum Abunyewa ${ }^{1)}$, \\ Victor Afari-Sefa ${ }^{2}$, and Richard Asare ${ }^{3)}$ \\ ${ }^{1)}$ Kwame Nkrumah University of Science and Technology, Department of Agroforestry, Kumasi, Ghana \\ ${ }^{2)}$ World Vegetable Center, Cotonou, Benin \\ ${ }^{3}$ International Institute of Tropical Agriculture, Accra, Ghana \\ ${ }^{*}$ ) Corresponding author: afeletennyson@gmail.com \\ Received: 21 September 2020 / Accepted: 19 November 2020
}

\begin{abstract}
Shade grown cocoa systems have been credited with stocking high quantities of carbon and therefore possess the potential to mitigate climate change. This study quantifies and compares carbon stored as well as estimated cocoa yields in two shade management types, i.e., shaded and full-sun across three agroecological zones: dry semi-deciduous fire zone (DSFZ), moist evergreen zone (MEZ) and upland evergreen moist zone (UEMZ) in Ghana. Results show that soil organic carbon (SOC) stored decreased with increasing soil depth across all agroecological zones. Cocoa farms with shade trees stored 6 times more soil carbon (35.90 $\left.\pm 1.56 \mathrm{Mg} \mathrm{C} \mathrm{ha}^{-1}\right)$ compared to the full-sun systems $\left(5.98 \pm 1.56 \mathrm{Mg} \mathrm{C}^{-\mathrm{ha}^{-1}}\right)$. Carbon stocks in DSFZ and MEZ were $61.73 \pm 1.02 \mathrm{Mg} \mathrm{C}^{-h^{-1}}$ and $67.46 \pm 1.02 \mathrm{Mg}$


zones, pod count in UEMZ and MEZ were similar but varied from that of DSFZ, which recorded the least. Wilting of pods and cherrelles, was minimal and similar in UMEZ and MEZ but was significantly higher in DSFZ. It is recommended that farmers should be encouraged through strong policies to adopt the integration of shade trees in the production of cocoa in Ghana to mitigate the effects of climate change.
\end{abstract}

Keywords: climate change, cocoa, carbon storage, shaded cocoa, full-sun cocoa

\section{INTRODUCTION}

Cocoa (Theobroma cacao L.) production is one of the most extensive land use systems in the agrarian landscape in Ghana with a coverage area of over 1.4 million ha from previously forested lands (Asare, 2019). Historically, smallholder farmers have expanded into forested areas in a bid to capitalize on fertile forest land to compensate for reduced yields experienced on existing cocoa lands. The average productivity of dry cocoa beans in Ghana is reported to be in the range of 400 $500 \mathrm{~kg} \cdot \mathrm{ha}^{-1}$ as against a potential of between
$1200-2000 \mathrm{~kg}^{-h a^{-1}}$ even though the country is noted as one of the top two producers worldwide (Asare, 2019). One of the major causes of this huge yield gap is poor soil fertility management coupled with low quality of cocoa planting materials, old average age of farmers (over 45 years), and prevalence of diseases and pests. In Ghana, the conversion rate of forest cover to cocoa farms is $1.4 \%$ to $2 \%$ per annum; this is more pronounced in the western region of the country where over $50 \%$ of the production comes from and where majority of the farms established are rapidly being converted to full sun production system (Amooh, 2017). 
The conversion of the humid forest zones into cropland negates a potential average carbon sequestration rate of about $16.9 \mathrm{t}$ C.ha ${ }^{-1}$ and the restoration of these lands back to their native vegetation could potentially store an additional $19.9 \mathrm{t} \mathrm{C}^{-\mathrm{ha}^{-1}}$. These values represent a change of about $18.6 \%$ between soil organic carbon (SOC) in the current land use and the native vegetation (Akpa et al., 2016). In effect, agricultural practices that contribute to SOC sequestration can contribute to mitigate climate change by converting atmospheric $\mathrm{CO}_{2}$ into soil carbon which is long-lived (Minasny et al., 2017). Carbon sequestration is the uptake and storage of atmospheric carbon in sinks such as trees and soils through either physical or biological mechanisms (Mekong River Commission, 2013; IPCC, 2001). Principally, carbon sequestration is the storage of carbon that would have been emitted to cause global warming in the atmosphere (Mekong River Commission, 2013). In a survey of SOC experiences in about 20 regions of the world, Minasny et al. (2017) posits that it is feasible to offset the current $\mathrm{CO}_{2}$ emissions by increasing SOC in agricultural land by improving management, afforesting degraded areas and conserving delicate land uses like native forest and peatlands.

Shade-grown cocoa (cocoa agroforestry) has been considered as one of the agricultural land management practices that can provide an alternative by turning cocoa production as a cause of forest degradation to reforestation and hence balancing the yield of cocoa and ecological integrity such as closed nutrient cycling, biodiversity conservation and carbon sequestration (Vaast \& Sommarriba, 2014). Cocoa agroforestry provides a medium for carbon storage by virtue of the presence of carbon sinks such as the soils, shade trees and the cocoa plants (Keenan \& Williams, 2018). According to the IPCC (2007), global carbon stocks in terrestrial ecosystem have reduced by $25 \%$ over the past 100 years.
In Ghana, the quest for increasing cocoa production has led to a drastic reduction of shade tree population in the cocoa landscape (Wade et al., 2010). In order to curb deforestation and increase carbon stocks, there is a need to encourage cocoa-shade tree association (Dixon, 1995), of which some Ghanaian farmers are already practicing. In Ghana, work done on the rate of carbon stocks in the cocoa ecosystem has been concentrated on tree-stored carbon (Asase \& Tetteh, 2016; Wade et al., 2010; Dawoe, 2009) with just a limited few (Mohammed et al., 2016) focused on the soil. However, according to Minasny et al. (2017) soil stores two to three times more carbon than the atmosphere and a relatively small increase in the stocks could exert a significant role in mitigating greenhouse gases emissions. This emphasizes the need to look deeper into the soils in addition to the vegetation above ground in the cocoa landscape to determine how much $\mathrm{C}$ is stored here and how this can translate into improving the soil fertility and mitigating greenhouse gases. This study was conducted to estimate organic carbon stored across three main agroecological zones of cocoa production in Ghana as against yields by documenting carbon stored in cocoa systems across three agroecological zones and determining the relationship between cocoa pod count and organic carbon stocks in Ghana.

\section{MATERIALS AND METHODS}

\section{Description of Study Sites}

A total of six districts were selected from three agroecological zones, which encompass the cocoa growing belt in Ghana (Figure 1). As shown in Table 1, two districts are from the dry semi-deciduous fire zone-(Offinso North and Offinso South), two from the upland evergreen moist zone (Atwima Nwabiagya and Atwima Mponua) and two districts from the 
moist evergreen zone (Sefwi Juaboso and Sefwi Wiawso). The Offinso North and South Districts experience double maxima rainfall regimes with an average annual rainfall of $953 \mathrm{~mm}$. The major raining season occurs in May to June, followed by a dry spell between August and September (GSS, 2010). The minor rains usually come in between September and November followed by dry harmattan till February.

The Atwima Nwabiagya and the Atwima Mponua districts fall within the Upland Evergreen Moist Zone with an average monthly temperature of about $20^{\circ} \mathrm{C}$ (GSS, 2010). A peak temperature of $28^{\circ} \mathrm{C}$ is recorded on March and April just around the time when the rains commence. The rainfall is made up of two distinct patterns. The main season is usually between March and July, peaking in June. The minor season stretches between late September and November. The average annual rainfall is between 1400-1700 $\mathrm{mm}$. The rainy days are between 105 and 115 days per year with $75 \%$ of these occurring in the major rainy season.

The Sefwi Wiawso and the Sefwi Juaboso districts fall within the moist evergreen zone. The districts are characterized by high amount of precipitation (MoFA, 2016). Annually the districts record as high as $1535 \mathrm{~mm}$ and $1780 \mathrm{~mm}$ rainfall respectively. The average temperature of the areas is about $28.2^{\circ} \mathrm{C}$ in March and about $24.5^{\circ} \mathrm{C}$ in August. The districts have high levels of precipitation. Humidity is moderately high, and ranges between 70-90\%. It has two long wet seasons isolated by a moderately short dry season. The dry season is set apart by moderately low humidity with hazy conditions occurring from December to February (MoFA, 2016; GSS, 2010).

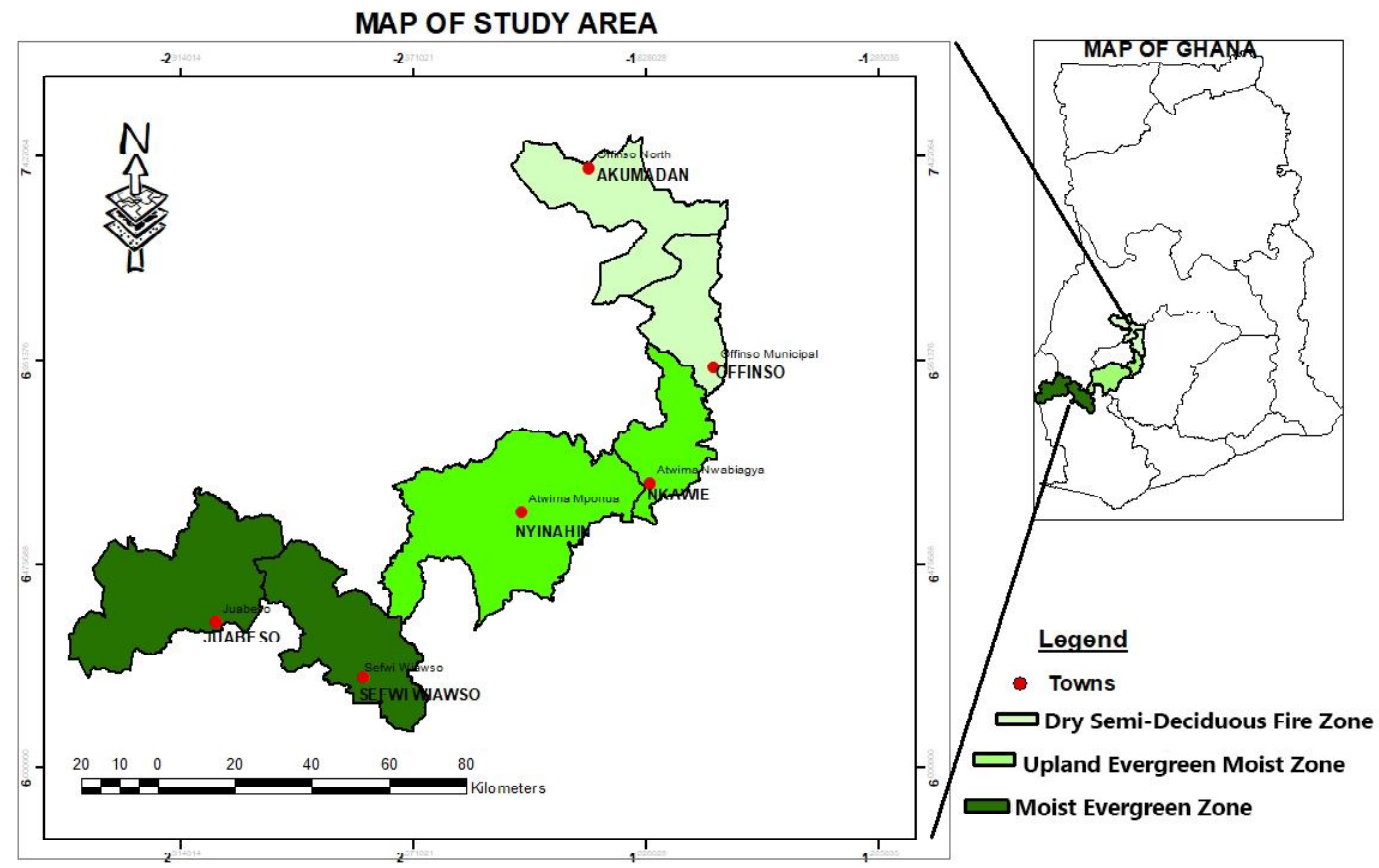

Figure 1. Map of the study sites showing six different districts across three agroecological zones 


\section{Experimental Plot and Procedure}

In each district, two productive farms (farms with good yield trends as per interviews with farmers and recommendations from Cocoa Health and Extension Officers) were chosen, one shaded and the other unshaded (full-sun). Farmers were interviewed to ascertain the ages of their farms, management practices (i.e. pruning regimes, pesticides and fungicides application, weeding and inorganic fertilizer/organic matter application) undertaken on the farm as well as land preparation methods used before cocoa establishment. Farms of similar age groups (15 years) were selected across all agroecological zones. At each farm, plot sizes of $30 \mathrm{~m} \times 90 \mathrm{~m}$ were demarcated for sampling at about $20 \mathrm{~m}$ away from the boundary of the farm so as to help reducing border effect on data collected. Two $30 \mathrm{~m}$ transects dividing the plot into three $30 \mathrm{~m} \times 30 \mathrm{~m}(\sim 0.27 \mathrm{ha})$ subplots were delineated to give three pseudo-replications per each farm.

All shade trees identified within plots were counted, and their diameters at breast height (DBH) measured. On the average, there were six trees per plot. The AGB (aboveground biomass) of the cocoa trees was estimated using the allometric model proposed by Torres et al. (2014).

AGB (Theobroma cacao L.) in kg.tree ${ }^{-1}$ $=1.0408 \exp ^{0.0736 \times(\mathrm{d} 30)}$, where $\mathrm{d} 30$ is the diameter of cocoa trees measured at a height of $30 \mathrm{~cm}$ from the ground.

Similarly, allometric equation by FAO (1997) was used to determine the biomass of shade trees on cocoa farms:

$$
\left(\mathrm{AGB}=\exp ^{[-2.134+2.530 * \ln (\mathrm{DBH})]}\right)
$$

Where AGB = estimated above-ground biomass in $\mathrm{kg}$, DBH (diameter at breast height $(1.3 \mathrm{~m}))$ in $\mathrm{cm}$. Below-ground biomass of the cocoa and shade trees was estimated by the use of Cairns et al. (1997).

$$
\left.\mathrm{BGB}=\exp ^{[-1.0587+0.8836 \ln (\mathrm{AGB})]}\right)
$$

After calculating the total amount of biomass in the measured areas it is converted to tonnes per hectare from the equation of Macias et al. (2017), as follows:

$$
\mathrm{AGB}=\sum \frac{\mathrm{SB}}{1000}\left(\frac{10000}{A R E A}\right)
$$

Where $\Sigma \mathrm{SB}=$ sum of tree biomass of all the measured cocoa trees in the area. Factor 1000 $=$ conversion of sample units in kilograms to tonnes and factor $10000=$ conversion of measuring area $\left(\mathrm{m}^{2}\right)$ to hectares. To estimate the amount of carbon stored in cocoa; we multiply the AGB $\times$ carbon fraction (0.475) $=$ Carbon in AGB (Saj et al., 2013).

Cocoa yield was also estimated using yield parameters such as the number of pods per tree, number of wilted pods and cherrelles. Carbon dioxide stored in the cocoa trees were estimated by converting the amount of carbon calculated from allometric equation to the amount of carbon dioxide stored (multiply by 3.6663 , molecular mass of carbon dioxide).

In addition, soil samples were randomly collected at three different depths, i.e. 0-20, $20-40,40-60) \mathrm{cm}$ from the selected farms for analysis. In each subplot on each farm, 3 soil samples were collected from 3 different depths, giving a total of 9 soil samples per farm and 108 soil samples in total from the three agroecological zones. Soil samples collected were used to determine soil bulk density and organic carbon concentration (\%C) using the core sampler method and the Walkley-Black chromic acid wet oxidation method, respectively, at the Soil Research Institute-Council for Scientific and Industrial Research, Kwadaso-Ghana.

Soil organic carbon stored (SOC) ton/ha was estimated as:

$$
\mathrm{SOC}=\% \mathrm{C} * \mathrm{D} * \rho d
$$


Table 1. GPS coordinates of farms on which data was taken in the various districts agroecological zone district community

\begin{tabular}{|c|c|c|c|c|}
\hline Agroecological zone & District & Community & Shade type & GPS coordinate \\
\hline Dry semi-deciduous fire zone & Offinso North & Akumadan & Full-sun & $\begin{array}{l}\text { N } 7^{\circ} 19^{\prime} 26.59116^{\prime \prime} \\
\text { W } 1^{\circ} 59^{\prime} 47.4828^{\prime \prime}\end{array}$ \\
\hline Dry semi-deciduous fire zone & Offinso North & Akumadan & Shaded & $\begin{array}{l}\text { N } 7^{\circ} 24^{\prime} 19.503^{\prime \prime} \\
\text { W } 1^{\circ} 53^{\prime} 21.64848^{\prime \prime}\end{array}$ \\
\hline Dry semi-deciduous fire zone & Offinso South & Mansara & Full-sun & $\begin{array}{l}\mathrm{N} 6^{\mathrm{O}} 56^{\prime} 07.3660^{\prime \prime} \\
\mathrm{W} 1^{\mathrm{O}} 45^{\prime} 07.320^{\prime \prime}\end{array}$ \\
\hline Dry semi-deciduous fire zone & Offinso South & Abira & Shaded & $\begin{array}{l}\mathrm{N} 6^{\circ} 54^{\prime} 45.94788^{\prime \prime} \\
\mathrm{W} 1^{\mathrm{O}} 43^{\prime} 4.82988^{\prime \prime}\end{array}$ \\
\hline Upland evergreen moist zone & Atwima Nwabiagya & Wiawso & Full-sun & $\begin{array}{l}\mathrm{N} 6^{\circ} 39^{\prime} 0.70884^{\prime \prime} \\
\mathrm{W} 1^{\mathrm{o}} 49^{\prime} 46.10532 "\end{array}$ \\
\hline Upland evergreen moist zone & Atwima Nwabiagya & Wiawso & Shaded & $\begin{array}{l}\mathrm{N} 6^{\circ} 38^{\prime} 58.28388^{\prime \prime} \\
\mathrm{W} 1^{\mathrm{O}} 50^{\prime} 4.236^{\prime \prime}\end{array}$ \\
\hline Upland evergreen moist zone & Atwima Mponua & Anniamoa & Full-sun & $\begin{array}{l}\text { N } 6^{\circ} 31^{\prime} 3.87984^{\prime \prime} \\
\text { W } 2^{\circ} 1^{\prime} 1.1622^{\prime \prime}\end{array}$ \\
\hline Upland evergreen moist zone & Atwima Mponua & Anniomoa & Shaded & $\begin{array}{l}\mathrm{N} 6^{\mathrm{O}} 36^{\prime} 3.7120^{\prime \prime} \\
\mathrm{W} 2^{\mathrm{O}} 2^{\prime} 1.120^{\prime \prime}\end{array}$ \\
\hline Moist evergreen zone & Sefwi Wiawso & Wiawso & Full-sun & $\begin{array}{l}\mathrm{N} 6^{\circ} 11^{\prime} 21.552^{\prime \prime} \\
\mathrm{W} 2^{\mathrm{O}} 30^{\prime} 7.7814^{\prime \prime}\end{array}$ \\
\hline Moist evergreen zone & Sefwi Wiawso & Adiembra & Shaded & $\begin{array}{l}\text { N 6 }{ }^{\circ} 12^{\prime} 27.75096^{\prime \prime} \\
\text { W } 2^{\mathrm{O}} 29^{\prime} 9.19068^{\prime \prime}\end{array}$ \\
\hline Moist evergreen zone & Sefwi Juaboso & Nkwanta & Full-sun & $\begin{array}{l}\text { N 6Ú 21'44.6094 } \\
\text { W 2Ú 49'59.91132 }\end{array}$ \\
\hline Moist evergreen zone & Sefwi Juaboso & Nkwanta & Shaded & $\begin{array}{l}\text { N 6Ú 23’20.7114 } \\
\text { W 2Ú 49’57.864 }\end{array}$ \\
\hline
\end{tabular}

Where D is soil depth (cm), $\rho d$ is the soil bulk density $\left(\mathrm{g} . \mathrm{cm}^{-3}\right) ; \mathrm{C}$ is the carbon concentration (\%). $\mathrm{CO}_{2}$ stored was determined by multiplying by 3.6663 (Dutta et al., 2017; Nowak et al., 2013).

\section{Data analysis}

Data from the study was subjected to the two-way ANOVA using Statistix 7.0 software with an alpha level of 5\%, Fisher's Least Significant Difference was used to separate significant means. The variables: cocoa yields and carbon stored were compared between shaded and unshaded cocoa farms in all three-cocoa producing agroecological zones in Ghana.

All farms were 15 years old. Common among shade trees identified on farms include: Entandrophragma angolense, Funtumia elastica, Milicia excelsa, Terminalia ivorensis, Terminalia superba and Alstonia boonei. Financial returns to stored carbon was estimated based on a market value of USD 5 to every $\mathrm{Mg} \mathrm{CO}_{2}$ stored per hectare in the absence of a baseline for this study (Somarriba et al., 2013).

\section{RESULTS AND DISCUSSION}

\section{Socio-economic characteristics}

A total of 12 farmers were interviewed (owners of farms on which plots were established for data collection across all agro-ecological zones). Twelve respondents included ten males and two females, all aged 45 years and above. Aside farmers in the UEMZ who indicated the application of organic matter in the form of poultry manure on their farms. Other cultural practices such as, pruning regimes, pesticides and fungicides application, weeding, inorganic fertilizer application and slash and burn method of land preparation were common to all farms.

This is due to the work load involved in cocoa farming which usually deter most women from engagement. This result agrees with findings of CRIG (2017) and Bymolt (2018), where in different studies conducted majority (above $50 \%$ ) identified cocoa farmers were men. All respondents $(\mathrm{n}=12)$ aged above 45 years. Ficks (2015) reported that one alarming concern hitting the cocoa production 
sector in Ghana is that of farmers' old age. With all other cultural practices in the production systems across the agroecological zones being the same, farmers in the UEMZ had access to poultry manure which they apply on farms. This is possible due to high number of poultry farms in the agroecological zone (MoFA, 2019).

\section{Soil Carbon Stocks}

SOC stored was significantly influenced by soil depth (A), districts (C) and $\mathrm{A} * \mathrm{C}$ interaction (Table 2). However, shade-type (B), $\mathrm{A} * \mathrm{~B}, \mathrm{~B} * \mathrm{C}$ and $\mathrm{A}^{*} \mathrm{~B}{ }^{*} \mathrm{C}$ interactions did not have significant influence on soil organic carbon stored (Table 2).

\section{Effect of Shade Type}

Mean soil organic carbon (SOC) stored in the shaded systems was $49.23 \pm 3.06 \mathrm{Mg}$ C.ha ${ }^{-1}$ and that of the full-sun system was
44.86 $\pm 3.06 \mathrm{Mg}$ C.ha $^{-1}$ but were not statistically significant $(p=0.127)$. Soil depths significantly influenced the SOC stored. SOC stored $\left(61.83 \pm 3.06 \mathrm{Mg} \mathrm{C}^{-h^{-1}}\right)$ at a depth of $0-20 \mathrm{~cm}$ and was significantly higher than at $20-40 \mathrm{~cm}$ depth $\left(45.22 \pm 3.06 \mathrm{Mg}\right.$ C.ha' $\left.{ }^{-1}\right)$ which was also significantly higher than that at $40-60 \mathrm{~cm}$ depth $\left(33.53 \pm 3.06 \mathrm{Mg} \mathrm{C} \mathrm{ha}^{-1}\right)$ (Figure 2).

Generally, there was a significant effect of agroecological zones on SOC stocks at various soil depths in the three agroecological zones with the highest recorded in the $0-20 \mathrm{~cm}$ depth of MEZ (Table 3). On the average, UEMZ recorded the highest SOC stored at $51.26 \pm 14.23 \mathrm{Mg} \mathrm{C} . \mathrm{ha}^{-1}$, compared to $50.30 \pm 14.23 \mathrm{Mg} \mathrm{C} \cdot \mathrm{ha}^{-1}$ and 39.03 $\pm 14.23 \mathrm{Mg} \mathrm{C}$ ha $^{-1}$ recorded in MEZ and DSFZ respectively. In each ecological zone, lower soil depths had significantly lower SOC stocks.

At the district level, analysis of variance of soil organic carbon in the six districts recorded significant differences in SOC at different

Table 2. Summary of Analysis of Variance of soil organic carbon stored across three agroecological zones in Ghana

\begin{tabular}{|c|c|c|c|c|c|}
\hline Source & df & SS & MS & $\mathrm{F}$ & p-value \\
\hline Depth (A) & 2 & 14562.60 & 7281.31 & 28.64 & 0.0000 \\
\hline Shade type (B) & 1 & 605.88 & 605.88 & 2.38 & 0.1270 \\
\hline District (C) & 5 & 3798.59 & 759.72 & 2.99 & 0.0166 \\
\hline $\mathrm{A}^{*} \mathrm{~B}$ & 2 & 1105.81 & 552.91 & 2.18 & 0.1210 \\
\hline $\mathrm{A}^{*} \mathrm{C}$ & 10 & 5175.65 & 517.57 & 2.04 & 0.0416 \\
\hline $\mathrm{B} * \mathrm{C}$ & 5 & 2089.01 & 417.80 & 1.64 & 0.1595 \\
\hline $\mathrm{A} * \mathrm{~B} * \mathrm{C}$ & 10 & 1428.64 & 142.86 & 0.56 & 0.8393 \\
\hline Error & 72 & 18301.8 & 254.19 & & \\
\hline Total & 107 & 47068.0 & & & \\
\hline
\end{tabular}

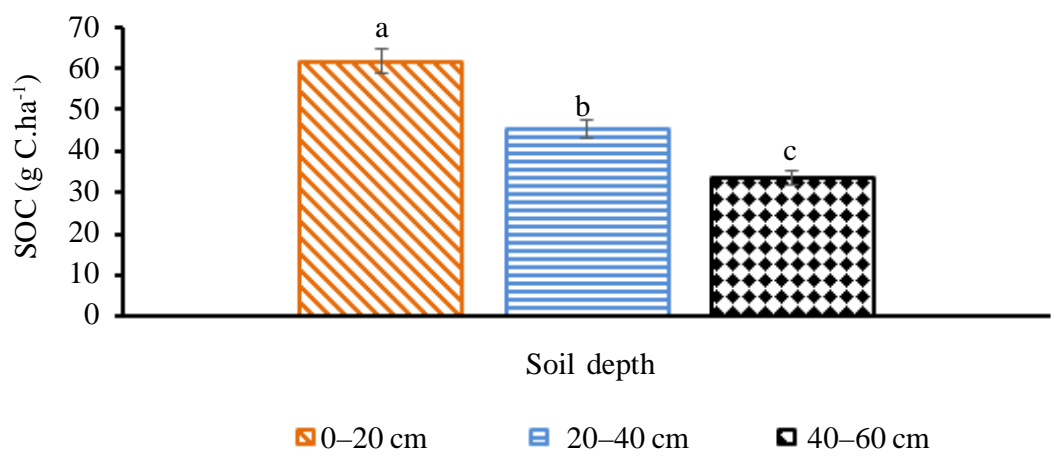

Figure 2. Soil organic carbon stored at three different soil depths across six cocoa districts in Ghana; Bars with different alphabets mean significantly different among treatments at $\alpha=5 \%$ 
soil depths in each district (Table 4). In the Atwima Nwabiagya district, SOC varied within the three depths with the $0-20 \mathrm{~cm}$ depth recording the highest of $75.59 \pm 13.39 \mathrm{Mg}$ C.ha ${ }^{-1}$, followed by the $20-40 \mathrm{~cm}$ depth $(45.82$ $\pm 23.73 \mathrm{Mg} \mathrm{C}^{-h^{-1}}$ ), and the 40-60 cm depth recording the least of $25.28 \pm 7.38 \mathrm{Mg} \mathrm{C} \mathrm{ha}^{-1}$. Soil organic carbon stored in cocoa systems in the Atwima Nwabiagya district followed similar trends to those of Sefwi Wiawso and Sefwi Juaboso districts where SOC recorded significantly decreased with depth (Table 4). Significant differences were observed in SOC stored among the six cocoa districts. The difference observed between Atwima Mponua $\left(53.62 \pm 5.31 \mathrm{Mg} \mathrm{C}\right.$ ha $\left.^{-1}\right)$ and Sefwi Wiawso districts $\left(52.48 \pm 5.31 \mathrm{Mg} \mathrm{C}^{-} \mathrm{ha}^{-1}\right)$ was marginal. These, however, were significantly higher than Atwima Nwabiagya $(48.90 \pm 5.31 \mathrm{Mg}$ C.ha ${ }^{-1}$ ) and Sefwi Juaboso districts (48.11 \pm $5.31 \mathrm{Mg} \mathrm{C}^{-h^{-1}}{ }^{-1}$, which had similar SOC stored. The Offinso South $(40.65 \pm 5.3 \mathrm{Mg}$ C.ha $\left.{ }^{-1}\right)$ and North $\left(37.40 \pm 5.31 \mathrm{Mg} \mathrm{C}^{-h^{-1}}\right)$ districts had the least and similar SOC.

The effect of shade type was significant only at Offinso South district in DSFZ, where SOC stored was $47.53 \pm 12.66 \mathrm{Mg}$ C.ha ${ }^{-1}$ under shade compared to the full-sun of 33.78 $\pm 7.91 \mathrm{Mg} \mathrm{C}^{-} \mathrm{ha}^{-1}$ (Table 5).
The average soil organic carbon (SOC) stored in 15-year-old shaded cocoa ecosystem (depth 0-60 cm) across the three agroecological zones was $49.23 \pm 23.51 \mathrm{Mg} \mathrm{C}^{-} \mathrm{ha}^{-1}$ compared to $44.46 \pm 20.94 \mathrm{Mg} \mathrm{C}^{-h a^{-1}}$ in full-sun but with no significant difference. This is consistent with results obtained by Dawoe (2009) and Mohammed et al. (2016) who also obtained similar trends even though with higher results. SOC stored decreased with increasing depth. These trends are attributed to high organic matter accumulation in the upper $30 \mathrm{~cm}$ depth of the soil mainly as a result of litter-fall and its subsequent decomposition (Mohammed et al., 2016; Gama-Rodrigues, 2010).

UEMZ recorded the highest SOC of $51.26 \pm 21.27 \mathrm{Mg} \mathrm{C}$ ha $^{-1}$ which was significantly different from that of MEZ (50.30 23.94 $\mathrm{Mg} \mathrm{C.ha-1)}$ and both were significantly higher than the amount observed $(39.03 \pm 14.23 \mathrm{Mg}$ ${\mathrm{C} . h a^{-1}}^{-1}$ in DSFZ. UEMZ recorded the highest SOC probably due to the application of poultry manure as indicated by farmers in this area.

The least SOC recorded in DSFZ could be due to low rainfall and dry weather conditions which could translate into lower decomposition (Rohr et al., 2013) compared to the two other relatively wet agroecological zones. According to Rohr et al. (2013), rainfall and soil moisture content affect SOC stored, less

Table 3. Mean soil organic carbon stored at three different soil depths in the three ecological zones

\begin{tabular}{|c|c|c|c|}
\hline Soil depth & $\begin{array}{l}\text { Dry semi-deciduous } \\
\text { fire zone }\end{array}$ & $\begin{array}{l}\text { Upland evergreen moist } \\
\text { forest zone }\end{array}$ & Moist evergreen zone \\
\hline & \multicolumn{3}{|c|}{ 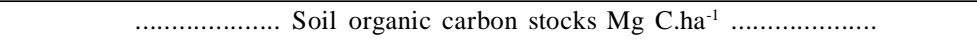 } \\
\hline $0-20 \mathrm{~cm}$ & $46.99 \pm 9.95^{\mathrm{a} \dagger}$ & $65.73 \pm 16.04^{\mathrm{a}}$ & $72.77 \pm 21.38^{\mathrm{a}}$ \\
\hline $20-40 \mathrm{~cm}$ & $39.42 \pm 15.79^{\mathrm{b}}$ & $50.76 \pm 21.76^{b}$ & $45.49 \pm 20.21^{\mathrm{b}}$ \\
\hline $40-60 \mathrm{~cm}$ & $30.67 \pm 12.26^{\mathrm{c}}$ & $37.29 \pm 18.32^{\mathrm{c}}$ & $32.63 \pm 6.68^{\mathrm{c}}$ \\
\hline $\mathrm{p}$-value & 0.0146 & 0.0033 & 0.0003 \\
\hline
\end{tabular}

Table 4. Soil organic carbon stored at different depths in the six cocoa growing districts

\begin{tabular}{|c|c|c|c|c|c|c|}
\hline Soil depth & $\begin{array}{l}\text { Offinso } \\
\text { North }\end{array}$ & $\begin{array}{l}\text { Offinso } \\
\text { South }\end{array}$ & $\begin{array}{c}\text { Atwima } \\
\text { Nwabiagya }\end{array}$ & $\begin{array}{l}\text { Atwima } \\
\text { Mponua }\end{array}$ & $\begin{array}{c}\text { Sefwi } \\
\text { Wiawso }\end{array}$ & $\begin{array}{c}\text { Sefwi } \\
\text { Juaboso }\end{array}$ \\
\hline & \multicolumn{6}{|c|}{ Soil organic carbon stocks $\mathrm{Mg} \mathrm{C} \mathrm{Cha}^{-1} \ldots \ldots \ldots \ldots \ldots \ldots$} \\
\hline $0-20 \mathrm{~cm}$ & $44.74 \pm 10.99$ & $49.24 \pm 9.22$ & $75.59 \pm 13.39^{\mathrm{a}}$ & $55.86 \pm 12.38$ & $77.68 \pm 24.77^{\mathrm{a}}$ & $67.86 \pm 18.29^{\mathrm{a}}$ \\
\hline $20-40 \mathrm{~cm}$ & $39.12 \pm 21.16$ & $39.72 \pm 10.05$ & $45.82 \pm 23.73^{\mathrm{b}}$ & $55.70 \pm 20.50$ & $47.58 \pm 25.37^{b}$ & $43.40 \pm 15.38^{\mathrm{b}}$ \\
\hline $40-60 \mathrm{~cm}$ & $28.40 \pm 11.69$ & $32.99 \pm 13.49$ & $25.28 \pm 7.38^{\mathrm{c}}$ & $49.29 \pm 18.39$ & $32.18 \pm 6.79^{c}$ & $33.09 \pm 7.17^{\mathrm{b}}$ \\
\hline p-value & 0.2035 & 0.0663 & 0.0003 & 0.7616 & 0.0058 & 0.0024 \\
\hline
\end{tabular}

Note: In each column, values followed by the same letter are not significantly different. 
Table 5. Soil organic carbon stored under different shade types in the six cocoa growing districts

\begin{tabular}{|c|c|c|c|c|c|c|}
\hline Soil depth & $\begin{array}{l}\text { Offinso } \\
\text { North }\end{array}$ & $\begin{array}{l}\text { Offinso } \\
\text { South }\end{array}$ & $\begin{array}{c}\text { Atwima } \\
\text { Nwabiagya }\end{array}$ & $\begin{array}{l}\text { Atwima } \\
\text { Mponua }\end{array}$ & $\begin{array}{c}\text { Sefwi } \\
\text { Wiawso } \\
\end{array}$ & $\begin{array}{c}\text { Sefwi } \\
\text { Juaboso }\end{array}$ \\
\hline & \multicolumn{6}{|c|}{ Soil organic carbon stocks Mg C.ha- ${ }^{-1}$} \\
\hline Shaded system & $34.59 \pm 11.63$ & $47.53 \pm 12.66^{\mathrm{a}^{*}}$ & $47.64 \pm 29.77$ & $51.85 \pm 19.008$ & $60.33 \pm 33.67$ & $53.43 \pm 23.85$ \\
\hline Full-sun system & $40.20 \pm 19.80$ & $33.78 \pm 7.91^{\mathrm{b}}$ & $50.15 \pm 23.84$ & $55.39 \pm 14.82$ & $44.63 \pm 18.59$ & $42.79 \pm 15.34$ \\
\hline p-value & 0.4746 & 0.0139 & 0.8458 & 0.6658 & 0.2386 & 0.2768 \\
\hline
\end{tabular}

rainfall generally leads to low SOC stored while high rainfall has the potential to store higher amount of SOC.

SOC stored with regards to depth across the six growing districts showed no significant differences with the exception of Atwima Nwabiagya, Sefwi Wiawso and Sefwi Juaboso. In all these three districts, SOC varied in the order 0-20 cm depth $>20-40 \mathrm{~cm}$ depth $>40$ $60 \mathrm{~cm}$ depth. The high SOC observed at Atwima Nwabiagya district could be attributed to poultry manure application. This is because the district is home to a large number of poultry farms and this accounts for farmers having better access to poultry manure which they apply to their farms.

In Sefwi Wiawso and Sefwi Juaboso the difference in SOC was as a result of high litter accumulation in the fields which serves as the primary source of SOC (Post \& Kwon, 2000). This high litter fall aided by good environmental conditions for decomposition, thus, soil surface temperature and soil moisture (Pandey et al., 2013), caused variations in the SOC stored (Post \& Kwon, 2000).

\section{Aboveground Tree Carbon Stored}

In general, across all the districts, shade grown cocoa significantly $(p=0.0000)$ influenced aboveground tree carbon stored compared to full-sun cocoa. Aboveground tree carbon stocks in the shaded production system $\left(35.90 \pm 1.56 \mathrm{Mg} \mathrm{C} \mathrm{ha}^{-1}\right)$ was significantly higher than the full-sun production system (5.98 \pm $1.56 \mathrm{Mg} \mathrm{C}^{-h^{-1}}$ ) in the three agroecological zones $(p=0.0000)$. In each agroecological zone, the shaded system significantly stored more carbon than the full-sun system (Table 6). At least more than three times the carbon stored in each full-sun system was in the shaded system across all agroecological zones. However, there were no marked variations between the three agroecological zones on carbon stored in above ground tree biomass.

Table 7 presents the effect of shadetype $\mathrm{x}$ district interaction on aboveground tree carbon stored. Aboveground tree carbon in the shaded system, ranged from a minimum of $15.41 \pm 0.003 \mathrm{Mg} \mathrm{C} \mathrm{ha}^{-1}$ in the Sefwi Wiawso District to a maximum of $55.09 \pm 0.003 \mathrm{Mg} \mathrm{C}^{-h^{-1}}$ in the Atwima Nwabiagya District (Table 7). However, in the full sun production system, Sefwi Wiawso District recorded the highest aboveground tree carbon of $7.34 \pm 0.003 \mathrm{Mg}$ C.ha ${ }^{-1}$ and Offinso North District recorded the lowest $\left(4.05 \pm 0.003 \mathrm{Mg} \mathrm{C}\right.$ ha $\left.^{-1}\right)$.

Results from the study showed significant differences between carbon stored in aboveground tree biomass of the full-sun cocoa production system and the shaded cocoa production system across the three agroecological zones with the shaded cocoa production system recording a higher mean carbon of $35.90 \pm 15.70 \mathrm{Mg} \mathrm{C}$ ha $^{-1}$. This trend could be due to the high amount of carbon stored in both the shade trees and that of the cocoa trees (Nadege et al., 2018). According to Nadege et al. (2018), associated trees in cocoa agroforestry systems store of up to about three times the amount of carbon stored in cocoa trees.

In each of the six districts, significant differences were observed in aboveground tree carbon stored between shaded and full- 
Table 6. Aboveground tree carbon stored in shaded and full-sun cocoa systems across three agroecological zones in Ghana

\begin{tabular}{|c|c|c|c|}
\hline Shade type & Dry Semi-deciduous Fire Zone & Upland Evergreen Moist Zone & Moist Evergreen Zone \\
\hline & & Mg C.ha ${ }^{-1}$ & \\
\hline Shaded system & $33.19 \pm 1.14^{\mathrm{a}}$ & $52.57 \pm 1.67^{\mathrm{a}}$ & $21.88 \pm 0.23^{\mathrm{a}}$ \\
\hline Full-sun system & $5.09 \pm 1.14^{\mathrm{b}}$ & $5.73 \pm 1.67^{\mathrm{b}}$ & $7.14 \pm 0.23^{\mathrm{b}}$ \\
\hline p-value & 0.0004 & 0.0000 & 0.0030 \\
\hline
\end{tabular}

Notes: Values with different letter in a column are significanly different; Figures are mean \pm S.E.

Table 7. Aboveground carbon stocks $\left(\mathrm{Mg} \mathrm{C}_{\mathrm{h}} \mathrm{ha}^{-1}\right)$ in the two shade types across six cocoa growing districts in Ghana

\begin{tabular}{lccccccc}
\hline Shade type & $\begin{array}{c}\text { Offinso } \\
\text { North }\end{array}$ & $\begin{array}{c}\text { Offinso } \\
\text { South }\end{array}$ & $\begin{array}{c}\text { Atwima } \\
\text { Nwabiaga }\end{array}$ & $\begin{array}{c}\text { Atwim } \\
\text { Mponua }\end{array}$ & $\begin{array}{c}\text { Sefwi } \\
\text { Wiawso }\end{array}$ & $\begin{array}{c}\text { Sefwi } \\
\text { Juaboso }\end{array}$ & P-velue \\
\hline \multirow{2}{*}{ Shaded system } & $45.13 \pm 0.003^{\mathrm{c} \dagger}$ & $21.24 \pm 0.003^{\mathrm{e}}$ & $\begin{array}{c}55.09 \pm 0.003^{\mathrm{a}} \\
5\end{array}$ & $50.06 \pm 0.003^{\mathrm{b}}$ & $15.41 \pm 0.003^{\mathrm{f}}$ & $30.35 \pm 0.003^{\mathrm{d}}$ & 0.0000 \\
Full-sun system & $4.05 \pm 0.003^{\mathrm{f}}$ & $6.14 \pm 0.003^{\mathrm{d}}$ & $4.21 \pm 0.003^{\mathrm{e}}$ & $7.25 \pm 0.003^{\mathrm{b}}$ & $7.34 \pm 0.003^{\mathrm{a}}$ & $6.93 \pm 0.003^{\mathrm{c}}$ & 0.0000 \\
\hline Notes : Values with different letter are significanly different; Figures are mean \pm S.E. & & &
\end{tabular}

sun system. The highest aboveground tree carbon was recorded for the shaded systems in UEMZ (Atwima Nwabiagya and Atwima Mponua) and the lowest estimates of aboveground tree carbon was in MEZ (Sefwi Wiawso and Sefwi Juaboso).

Studies of Martinez-Alcantara et al., (2016) showed that organic fertilizers with animal base component exhibit higher total biomass with a more profuse development of new organs such as leaves and roots as well as increasing the trees total biomass. This likely, accounts for the high aboveground tree carbon estimated from UEMZ.

The shaded farms in MEZ relatively had less shade tree density compared to the other districts due to high shade tree removal rates from cocoa farms in this zone (Amooh, 2017). The condition may have resulted in relatively higher water stress on the farm through soil water evaporation (Lin, 2010) that may have led to less aboveground biomass development (Mohammed et al., 2016; Ferreira et al., 2015). This finding is consistent with studies of Abdulai et al. (2017), where authors observed higher evapotranspiration rates of shaded cocoa production systems due to harsh climatic conditions including drought and high temperatures.

The condition in DSFZ, which has drier environmental conditions also causes slower growth of trees (UoU, 2019; William et al., 2019) hence relatively lower biomass accumulation (lower aboveground tree carbon) compared to UEMZ.

\section{Belowground Trees Carbon Stored}

In general, carbon stored in belowground tree biomass in the shaded system (2.95 \pm $0.12 \mathrm{Mg} \mathrm{C} \mathrm{ha}^{-1}$ ) was significantly higher than in the full sun system $\left(0.61 \pm 0.12 \mathrm{Mg} \mathrm{C} \cdot \mathrm{ha}^{-1}\right)$. Carbon stored in the roots of the trees showed significant variations between the two shade types in all the three ecological zones (Figure 3). DSFZ recorded $2.76 \pm 0.93$ and $0.52 \pm 0.10$ for shaded and full sun systems respectively

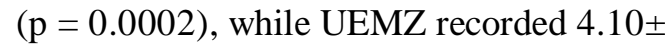
$0.11 \mathrm{Mg} \mathrm{C} \mathrm{ha}^{-1}$ and $0.59 \pm 0.15 \mathrm{Mg} \mathrm{C} \cdot \mathrm{ha}^{-1}$ for shaded and full sun systems, respectively $(\mathrm{p}=0.0000)$ while MEZ recorded 1.94 \pm 0.76Mg C.ha ${ }^{-1}$ and $0.71 \pm 0.03 \mathrm{Mg} \mathrm{C}^{-} \mathrm{ha}^{-1}$ for shaded and the full sun systems, respectively $(p=0.002)$. Differences observed between the three ecological zones in carbon stored in the shaded cocoa production systems were significant $(\mathrm{p}=0.0010)$, whiles the carbon stored in the full sun system across the three agroecological zones were similar (Figure 3).

Carbon stored in the belowground biomass in the six districts varied with shadetype, with the shaded system being signifi- 
cantly higher than the full-sun system. Unlike that of the aboveground tree carbon stored, across the six districts, the carbon stored in a particular shade type was not significantly different from the same shade type in another district (Table 8).

In each agroecological zone, belowground tree biomass carbon was observed to be markedly lower than SOC stored. The mean carbon (belowground tree carbon + aboveground tree carbon + SOC) stored in UEMZ was $55.95 \pm 1.03 \mathrm{Mg} \mathrm{C} \mathrm{Ca}^{-1}$ and was significantly higher than $\left(52.95 \pm 1.03 \mathrm{Mg} \mathrm{C}^{-h^{-1}}\right)$ in MEZ, these were however higher than $(42.32 \pm 1.03$ $\left.\mathrm{Mg} \mathrm{C} \cdot \mathrm{ha}^{-1}\right)$ in DSDFZ. Generally, total carbon stored across the three agroecological zones showed no significant differences, and values recorded were $61.73 \pm 1.02 \mathrm{Mg} \mathrm{C}^{-} \mathrm{ha}^{-1}$ for DSFZ,

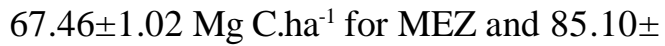
$1.02 \mathrm{Mg} \mathrm{C}^{-\mathrm{ha}^{-1}}$ for UEMZ (Figure 4).
There was significant difference in belowground tree biomass between the two shade types where the shaded cocoa production system recorded a higher value of $2.95 \pm$ 1.14 Mg C.ha- ${ }^{-1}$ compared to the full sun of $0.61 \pm 0.12 \mathrm{Mg} \mathrm{C} \mathrm{ha}^{-1}$. This follows a similar pattern as aboveground tree biomass carbon stored due to the inclusion of shade trees in estimating carbon stored in shaded farms (Nadege et al., 2018; Mohammed et al., 2016). Values here are lesser compared to that of aboveground biomass because of the allometric equation employed (Cairns et al., 1997) in our study, which reduces the aboveground tree biomass to below 24\% (Asase \& Tetteh, 2016). From the estimation of the aboveground tree carbon in this study, the shaded system was significantly different from the full sun system hence an observed similar trend in their belowground tree biomass. The differences

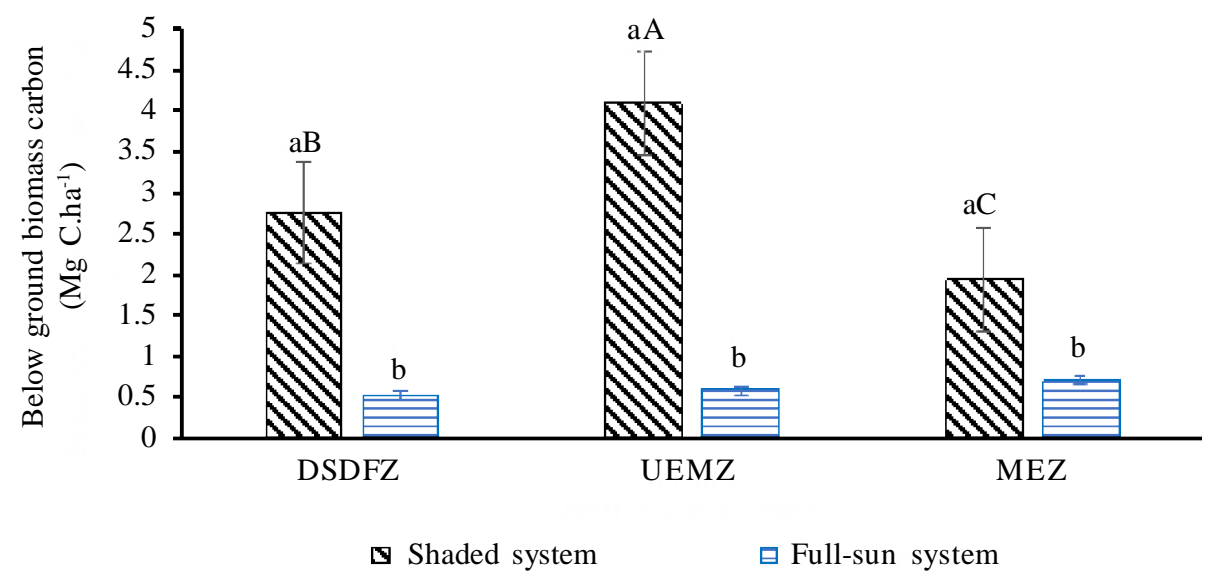

Figure 3. Belowground biomass carbon stored across three agroecological zones in Ghana; DSFZ (dry semi-deciduous fire zone), UEMZ (upland evergreen moist zone) and MEZ (moist evergreen zone); Bars with different alphabets mean significantly different among treatments; Uppercases are for shaded system in different agroecological zones while lower cases are for different shade types in the same agroecological zones at $\alpha=5 \%$

Table 8. Effect of shade-type on belowground biomass carbon stocks ( $\mathrm{Mg} \mathrm{C}^{-\mathrm{ha}^{-1}}$ ) across six cocoa growing districts

\begin{tabular}{|c|c|c|c|c|c|c|}
\hline Shade type & $\begin{array}{c}\text { Offinso } \\
\text { South }\end{array}$ & $\begin{array}{l}\text { Offinso } \\
\text { North }\end{array}$ & $\begin{array}{c}\text { Atwima } \\
\text { Nwabiagya }\end{array}$ & $\begin{array}{l}\text { Atwima } \\
\text { Mponua }\end{array}$ & $\begin{array}{c}\text { Sefwi } \\
\text { Wiawso }\end{array}$ & $\begin{array}{c}\text { Sefwi } \\
\text { Juaboso }\end{array}$ \\
\hline & \multicolumn{6}{|c|}{ 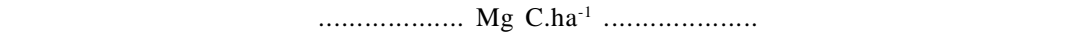 } \\
\hline Shaded system & $1.88 \pm 0.001^{\mathrm{a}}$ & $3.65 \pm 0.002^{\mathrm{a}}$ & $4.21 \pm 0.001^{\mathrm{a}}$ & $4.00 \pm 0.001^{\mathrm{a}}$ & $1.25 \pm 0.001^{\mathrm{a}}$ & $2.63 \pm 0.004^{\mathrm{a}}$ \\
\hline Full-sun system & $0.62 \pm 0.001^{\mathrm{b}}$ & $0.43 \pm 0.002^{\mathrm{b}}$ & $0.45 \pm 0.001^{\mathrm{b}}$ & $0.72 \mathrm{c} 0.001^{\mathrm{b}}$ & $0.73 \pm 0.001^{\mathrm{b}}$ & $0.69 \pm 0.004^{\mathrm{b}}$ \\
\hline p-value & 0.0000 & 0.0000 & 0.0000 & 0.0000 & 0.0000 & 0.0000 \\
\hline
\end{tabular}

Notes: Values with different superscript in a column are significantly different. Figures are mean \pm S.E. 


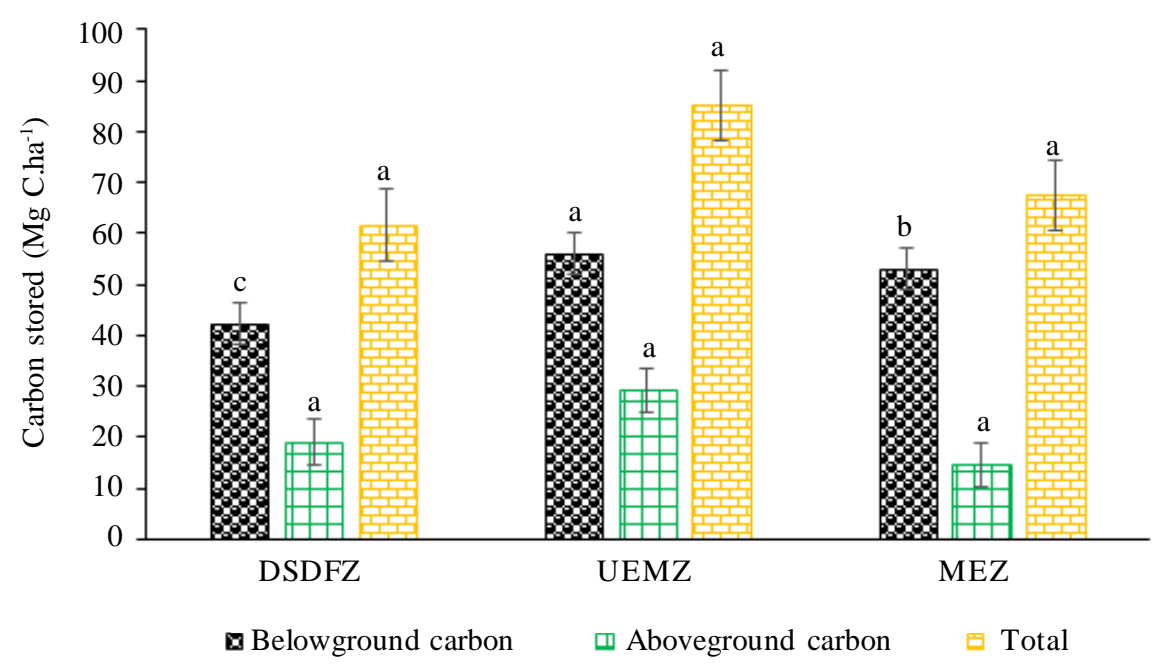

Figure 4. Total carbon (below ground tree carbon + above ground tree carbon + soil organic carbon) in the ecosystems of the three-cocoa producing agroecological zones in Mg C.ha ${ }^{-1}$; DSFZ (dry semi-deciduous fire zone, UEMZ (upland evergreen moist zone) and MEZ (moist evergreen zone); Bars with different alphabets mean significantly different among treatments at $\alpha=5 \%$

observed could possibly be attributed to poultry application on the farms of UEMZ (MartinezAlcantara et al., 2016) and dry weather conditions of DSDMZ (GSS, 2010; Lin, 2010).

The shaded cocoa systems stored higher carbon in the belowground tree biomass as compared to the full sun systems, due to the presence of shade trees (Nadege et al., 2018). The mean below ground organic carbon (soil organic $\mathrm{C}+$ belowground tree carbon) in the three agroecological zones, observed was 50.4 $\mathrm{Mg} \mathrm{C} . \mathrm{ha}^{-1}$. In the study of Sommarriba et al. (2013), 55.9 Mg C.ha- ${ }^{-1}$ for 18-year-old cocoa farms in Alta Verapaz, Guatemala was reported. The relatively lower organic carbon value observed in this study could be due to the younger age (15 years) of farms used. According to Kohl et al. (2017) and King (2014), trees develop faster and accumulate much more biomass as they age, hence higher organic carbon content.

\section{Total Carbon Stored and Financial Returns}

Total carbon dioxide equivalents estimated from the various agroecological zones are
226.3 $\mathrm{Mg} \mathrm{CO}_{2} \cdot$ ha $^{-1}, 312.0 \mathrm{Mg} \mathrm{CO}_{2} \cdot \mathrm{ha}^{-1}$ and 247.4 $\mathrm{Mg} \mathrm{CO}_{2} \cdot$ ha $^{-1}$ for the DSFZ, UEMZ, and MEZ respectively (Table 9). Estimated financial returns from these agroecological zones respectively are USD1,131.5; USD1,560; and USD1,237; giving an estimated total of USD3,928.50 (Table 9).

In the absence of a baseline data, and assuming that the additional amount of carbon added to each of the systems over their lifespan are as indicated in Table 9. The potential estimated financial returns in each of the ecological zones as estimated are respectively, USD1,131.5; USD1,560; and USD1,237 for the DSFZ, UEMZ and MEZ. The entire system potentially then stands to earn USD3,928.5 at the rate of USD5 to every $\mathrm{Mg} \mathrm{CO}_{2}$ stored per hectare.

\section{Cocoa Pod Count}

Analysis of variance for pod counts revealed that there were notable differences between number of cocoa pods found on trees in the two shade systems $(\mathrm{p}=0.0000)$. The full-sun system recorded higher number 
of pods with a mean count of $674 \pm 132$ ha $^{-1}$ across all agroecological zones and the shaded system recorded a mean pod count of $456 \pm 132 \mathrm{ha}^{-1}$.

The three agroecological zones showed significant differences in cocoa pod count. DSFZ recorded a mean pod count of $387 \pm 120$ ha $^{-1}$ which was significantly lower compared to what was recorded at MEZ $\left(693 \pm 120 \mathrm{ha}^{-1}\right)$ and UEMZ (614 $\left.\pm 120 \mathrm{ha}^{-1}\right)$ (Figure 5).

Significant differences $(\mathrm{p}=0.0008)$ were observed in cocoa pod count between the different districts (Figure 6). The analysis revealed that pods count at Sefwi Wiawso, Sefwi Juaboso and Atwima Nwabiagya districts recorded marginal differences. However, the pod counts recorded in these three districts were significantly higher than recorded at South Offinso and Atwima Mponua Districts (Figure 6). Offinso North District recorded markedly the lowest cocoa pod counts (Figure 6).

Shade-type had significant effect on the number of wilted pods and cherelles in the three agroecological zones. Generally, full sun production system recorded significantly higher number of wilted pods and cherelles $\left(186 \pm 40 \mathrm{ha}^{-1}\right)$ compared to the shaded system which recorded $51 \pm 40 \mathrm{ha}^{-1}$. Significant differences in wilted pod and cherelles were observed across the three agroecological zones (Figure 7). MEZ recorded the least number of wilted pod and cherelles per ha $\left(21 \pm 03 \mathrm{ha}^{-1}\right)$, which was similar to what was recorded at UEMZ, $49 \pm 03 \mathrm{ha}^{-1}$ wilted pods and cherelles. DSFZ however, recorded $285 \pm 03$ ha $^{-1}$ wilted pods and cherelles and this was significantly higher than the other agroecological zones (Figure 7).

\section{Organic Carbon Stored and Pod Count Relationship}

The relationship between carbon stored and cocoa pod counts across agroecological 




Agro-ecological zones

$$
\triangle \mathrm{DSDFZ} \text { घEMZ } \quad \mathrm{MEZ}
$$

Figure 5. Pod counts in the three-cocoa growing agroecological zones. DSFZ (Dry Semi-Deciduous Fire Zone, UEMZ (Upland Evergreen Moist Zone) and MEZ (Moist Evergreen Zone); Bars with different alphabets mean significantly different among treatments



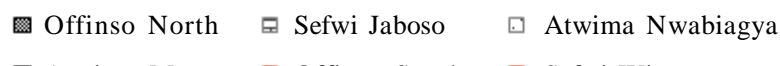

曰 Atwima Mponua $\otimes$ Offinso South Sefwi Wiawso

Figure 6. Cocoa pod counts in six cocoa growing districts across Ghana; Bars with different alphabets mean significantly different among treatments at $\alpha=5 \%$



Figure 7. Number of wilted pods and cherrels across three cocoa growing agroecological zones; DSFZ (dry semi-deciduous fire zone), UEMZ (upland evergreen moist zone) and MEZ (moist evergreen zone); Bars with different alphabets mean significantly different among treatments at $\alpha=5 \%$ 
zones as shown in Figure 8 is possibly a reflection of how $\mathrm{C}$ stocks may influence cocoa yields. Though not significant $(\mathrm{p}=0.3325)$, with an $R^{2}=0.2405$ there generally appears to be a positive relation between changes in C stocks and cocoa pod counts, with pod numbers increasing with increasing $\mathrm{C}$ stocks.

Acrros the three agroecological zones, MEZ (Sefwi Wiawso and Sefwi Juaboso) and UEMZ (Atwima Nwabiagya and Atwima Mponua) recorded the highest number of pods. The two zones, MEZ and UEMZ, however, had significantly higher number of pods than what was recorded in DSFZ (Offinso North and Offinso South). Higher yields in UEMZ and MEZ can be attributed to more favourable rainfall conditions (Vigneri, 2007) compared to DSFZ. Yields from the MEZ in the Western region were higher than in DSFZ in the Ashanti region and this is consistent with Asare et al. (2018) and Madsen \& Helledie (2018).

The wilted cherelles in the full sun system were about 3.5 times more than those in the shaded system. Again, the wilted cherelles in DSFZ was 5 times higher than what was observed in MEZ and UEMZ. This could be due to the presence of intense sunlight and rapid soil water evaporation in the full sun system. Moreover, in DSFZ, there is less rainfall and high amounts of sunlight (GSS, 2010). This enhanced the effect of evapotranspiration leading to high numbers of cherelles wilting (Handley, 2016; Carr \& Lockwood, 2011; Daymond \& Hadley, 2008; Hadley et al., 1994). This pattern probably explains the trend in yield in DSFZ recording significantly lower number of pods per hectare compared to the MEZ and UEMZ.

This study shows that full sun systems recorded significantly higher number of pods compared with shaded system across all zones. This observation is consistent with Asare et al. (2017), where the authors reported higher yields at plot level of full sun cocoa on a larger scale, Asare et al. (2018) recorded increasing yields of cocoa at farm level when shade cover increased from zero to about $34 \%$ cover. The findings of increased production at $30-50 \%$ shade cover have also been confirmed by Blaser et al. (2018) and Andreas et al. (2018). Hence, the debate on whether full-sun produces better than shaded cocoa must be put in perspective in terms of the amount of shade cover present rather than applying a blanket observation by authors who argue removal of shade trees from cocoa farms leads to increased yield (Madsen \& Helledie, 2018; Wade et al., 2010; Padi \& Owusu, 1998) without looking at the entire

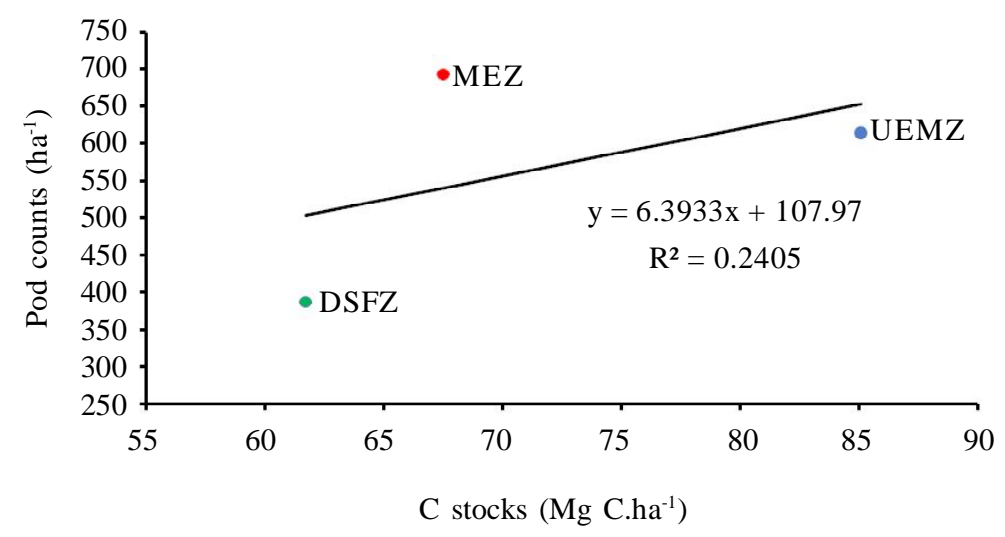

Figure 8. Relationship between carbon stored and cocoa pod counts across three agroecological zones in Ghana 
environmental integrity and sustainability of the farming system in time and space.

Apart from the fact that the effective life span of full-sun cocoa does not go beyond 10 years, there is also an additional effect of high insect and weed infestation, high nutrient and agrochemical demand coupled with the need for a well distribution of rain fall (Ahenkorah et al., 1987; Ahenkorah et al., 1974). Since these demands in most cases do not represent the reality of the smallholder farmers, the full-sun system turns to be more expensive both economically and environmentally to these farmers. Thus, according to Beer (1987) shaded cocoa provides an alternative that is ecologically and economically beneficial, especially in the situation where sustainability rather than maximization of productivity is of major concern.

Carbon stored in Ghana's cocoa ecosystem is closely associated with cocoa pod counts. An analysis of the works of Kimball \& Idso (1983) and Sommariba et al. (2013) suggest a possible increase in yield due to increase in carbon stored. Vaast \& Sommariba (2014) also hinted a similar concept by reporting that cocoa agroforestry systems have the potential to bridge the gap between cocoa yields and ecological integrity such as biodiversity conservation and carbon stocks. According to Derying et al. (2016), rising amounts of carbon stored in plants leads to higher rates of photo-synthesis and also reduction in plant water loss via transpiration which causes better growth and yield boost. Hence, not only will this stored carbon improve productivity, it will also reduce the $\mathrm{CO}_{2}$ levels in the atmosphere.

It is therefore recommended that farmers should be encouraged to include shade trees in cocoa farms by governmental programs that provides monitory support to these farmers starting with payment on carbon stored in the system, as this automatically yields the highest returns to the monetary value of carbon stored. This will help conserve and enhance the cocoa production system for it to become more climate-smart and help in achieving environmental programs targeted at reducing $\mathrm{CO}_{2}$ emission in the atmosphere. Enabling government policies that emphasize the co-benefits of agroforestry and assisting farmers in planting and maintenance of new trees on cocoa fields, would go a long way to add a social dimension to the multiple agroforestry co-benefits.

\section{CONCLUSIONS}

The cocoa ecosystem of Ghana accounts for high amounts of organic carbon especially in the shaded system referred to as cocoa agroforests. On the contrary, yield trends indicated that shaded farms have less yields compared to non-shaded farms. Hence, to make these management systems viable for farmers in order to improve carbon storage in the cocoa landscape, there should be a compensatory mechanism that will incentivize farmers to practice cocoa agroforestry.

\section{ACKNOWLEDGEMENTS}

The authors of this paper wish to acknowledge the International Institute of Tropical Agriculture (IITA) for funding this research study and Eunice Nimo (Kwame Nkrumah University of Science and Technology, Department of Agroforestry, Ghana) for help offered in data collection and analysis. The study forms part of the CGIAR programs on Climate Change, Agriculture and Food Security (CCAFS) and the Cocoa Soils project.

\section{REFERENCES}

Abdulai, I.; L. Jassogne.; S. Graefe; A. Asare; P. Van Asten \& P. Läderach (2017). Characterization of cocoa production, income diversification and shade tree 
management along a climate gradient in Ghana. PLOS ONE, 13, 1-15.

Ahenkorah, Y.; B. Halm; M. Appiah; G. Akrofi \& J. Yirenkyi (1987). Twenty years' results from a shade and fertilizer trial on Amazon cocoa (Theobroma cacao) in Ghana. Experimental Agriculture, 23, 31-39.

Ahenkorah, Y.; G. Akrofi \& A. Adri (1974). The end of the first cocoa shade and manurial experiment at the cocoa research institute of Ghana. Journal of Horticultural Sciences, 49, 43-51.

Akpa, S.I.C.; I.O.A. Odeh; T.F.A. Bishop; A.E. Hartermink \& I.Y. Amapu (2016). Total soil organic carbon and carbon sequestration potential in Nigeria. Geoderma, 271, 202-215.

Amooh (2017). Shade Management Options in Cocoa Agroforestry Systems in Two Ecological Zones in Ghana. MPhil Thesis. KNUST, Kumasi-Ghana.

Asare, R. (2019). The nexus between cocoa production and deforestation. Grain De Sel, 78, 26-27.

Asare, R.; M. Bo; R.A. Asare; G. Anim-Kwapong \& A. Ræbild (2018). On-farm cocoa yields increase with canopy cover of shade trees in two agroeco-logical zones in Ghana. Climate and Development, 11, 435-445.

Asare, R.; R.A. Asare; W. Asante; B. Markussen \& A. Ræbild (2017). Influences of shading and fertilization on on-farm yields of cocoa in Ghana. Experimental Agriculture, 53, 416-431.

Asase, A. \& D.A. Tetteh (2016). Tree diversity, carbon stocks, and soil nutrients in cocoa-dominated and mixed food crops agroforestry systems compared to natural forest in South-East Ghana. Agroecology and Sustainable Food Systems, 40, 96-113.

Beer, J. (1987). Advantages, disadvantages and desirable characteristics of shade trees for coffee, cacao and tea. Agroforestry Systems, 5, 3-13.
Blaser, J.W.; J. Oppong; S.P. Hart; J. Landolt; E. Yeboah \& J. Six (2018). Climate-smart sustainable agriculture in low-to-intermediate shade agroforests. Nature Sustainability, 1, 234-239.

Bymolt, R.; A. Laven \& M. Tyszler (2018). Gender and Cocoa. Demystifying the Cocoa Sector In Ghana and Cote d'voire. Chapter 14. The Royal Tropical Institute. Amsterdam, Netherlands.

Cairns, M.A.; S. Brown; H.E. Helmer \& G.A. Baumgardner (1997). Root biomass allocation in the world's upland forests. Oecologia, 111, 1-11.

Carr, K.V.M. \& G. Lockwood (2011). The water relations and irrigation requirements of cocoa (Theobroma cacao L.) : A review. Experimental Agriculture, 47, 653-676.

CRIG (2017). Report On Land Tenure and Cocoa Production In Ghana. A CRIG/WCF Collaboration Survey. Ghana.

Dawoe (2009). Conversion of Natural Forest to Cocoa Agroforest in Lowland Humid Ghana: Impact on Plant Biomass Production, Organic Carbon and Nutrient Dynamics. PhD Thesis, KNUST. Kumasi-Ghana.

Daymond, A.J. \& P. Hadley (2008). Differential effects of temperature on fruit development and bean quality of contrasting genotypes of cacao (Theobroma cacao). Annals of Applied Biology, 153 (2), 175-185.

Derying, D.; J. Elliott; E.C. Folberth; C. Muller; A.M. Pugh; J.K. Boote; D. Conway; A.C. Ruane; D. Gerten; W.J. Jones; N. Khabarov; S. Olin; S. Schaphoff; E. Schmid; H. Yang \& C. Rosenzweig (2016). Regional disparities in the beneficial effect of rising $\mathrm{CO}_{2}$ concentrations on crop water productivity. Nature Climate Change, 6, 786-790.

Dixon, R. (1995). Sources of sinks of greenhouse gasses. Agroforestry Systems, 31, 99-116.

Dutta, D.N.; A.L. Ravisanker; P.C. Meena; L.K. Ghasal; A.K. Kumar; A.S. Panwar \& 
S. Bhaskar (2017). Carbon sequestration and GHG measurement in IFModels, ICAR-AICP on Integrated Farming systems. p. 31-33. In: Proceedings of ICAR-Indian Institute of Farming Systems Research Conference. Modipuran Meerut, Uttar Predash, India.

FAO (1997). Estimating Biomass and Biomass Change of Tropical Forests: A Primer. FAO Forestry Paper, 200. 154. Rome, Italy

Ferreira, N.W.; F.C. Lacerda; C.R. Costa \& M.S. Filho (2015). Effect of water stress on species with different abundance: The importance of stress resistance syndrome in secondary dry tropical forest. Acta Botanica Brasilica, 29, 1-9.

Gama-Rodrigues, E.F.; P.K.R. Nair; D.V. Nair; A.C. Gama-Rodrigues; V.C. Baligar \& R.C.R. Marchado (2010). Carbon storage in soil size fractions under two cocoa agroforestry systems in Bahia, Brazil. Environmental Management, 45, 274-283.

GSS (2014). 2010 Population and housing census. District Analytical Report-Sefwi Wiawso Municipal District. Ghana Statistical Service.

Hadley, P. (2016). The Effect of Climate Change on Reproduction of Theobroma cacao $\mathrm{L}$. PhD Thesis. University of Reading. UK.

Hadley, P.; M. End; S.T. Taylor \& G.L. Pettipher (1994). Environmental regulation of vegetative and reproductive growth in cocoa grown in controlled glasshouse conditions. p. 319-331. In: Proceedings of the International Cocoa Conference: Challenges in the 90s. Kuala Lumpur, Malaysia.

IPCC (2001). Climate Change 2001: The Scientific Basis. Contribution of Working Group I to the Third Assesment Report Intergovermental Panel on Climate Change. Cambridge University Press. Cambridge.

IPCC (2007). Climate Change 2007: The Scientific Basis. Contribution of Working Group I to the Fourth Assesment Report Intergovermental Panel on Climate Change. Cambridge University Press. Cambridge.
Keenan, T.F. \& C.A. Williams (2018). The terrestrial carbon sinks: Annual review. Environment and Resources, 43(1), 219-243.

Kimball, B.A. \& S.B Idso (1983). Increasing Atmospheric $\mathrm{CO}_{2}$ Effects on Crop Yield, Water Use and Climate. U.S. Water Conservation Laboratory. Broadway, Phoenix. U.S.A.

King, B. (2014). Trees Grow Faster and Store More Carbon as They Age. Smithsonian Tropical Research Institute, Tropical Forest Canopy in Panama. Panama.

Kohl, M.; P.R. Neupane \& N. Loftfiomran (2017). The impact of tree age on biomass growth and carbon accumulation capacity. A retrospective analysis using tree ring data of three tropical tree species in natural forest of Suriname. Biodiversity Conservation. PLOS ONE, 12, 1-18.

Lin, B.B. (2010). The role of agroforestry in reducing water loss through soil evaporation and crop transpiration in coffee agroecosystem. Agriculture and Forest Meterology, 150, 510-518.

Macías, C.A.S.; O.J.C. Alegre \& A.S. Iglesias (2017). Estimation of above-ground live biomass and carbon stocks in different plant formations and in the soil of dry forests of the Ecuadorian coast. Food and Energy Security, 6, 1-7.

Madsen \& Helledie (2018). Climate Change Effect on Cocoa Production in Ghana. A Case Study of Full Sun and Agroforestry Systems in Ashanti and Western Regions. Master's Thesis. University of Copenhagen, Faculty of Science. Denmark.

Martinez-Alcantara, B.; M.R. Martinez-Cuenca; A. Bermejo; F. Legaz \& A. Quonones, (2016). Liquid organic fertilizers for sustainable agriculture: Nutrient uptake of organic versus mineral fertilizers in citrus trees. PLOS ONE, 11, 1-20.

Mekong River Commission (2013). Climate Change and Adaptation Initiative. Glossary of Terms and Definitions on Climate Change and Adaptation. 
Minasny, B.; B.P. Malone; A.B. McBratney; D.A. Angers; D. Arrouays; A. Chambers; V. Chaplot; Z.S. Chen; K. Cheng; B.S. Das $\&$ D.J. Field (2017). Soil carbon 4 per mille. Geoderma, 292, 59-86.

MoFA (2016). Annual Report. Ministry of Food and Agriculture. Accra, Ghana.

MoFA (2019). Analysis Poultry Sector Ghana 2019. An update on the opportunities and challenges. Netherlands Enterprise Agency, Netherland, 1-22.

Mohammed, M.A.; J.S. Robinson; D. Midmore \& A.Verhoef (2016). Carbon storage in Ghanaian cocoa ecosystem. Carbon Balance and Management, 2-8.

Nadège, M.T.; L. Zapfack; D.C. Chimi; B.L. Kabelong; P.F. Forbi; T.I. Tsopmejio; V.C. Tajeukem; Y.A.F. Ntonmen; M.R.B. Tabue \& J.M. Nasang (2018). Carbon storage potential of cacao agroforestry systems of different age and management intensity. Climate and Development, 11, 543-554.

Nowak, J.D.; E.F. Greenfield; R.E. Hoehn \& E. Lapoint (2013). Carbon storage and sequestration by trees in urban and community areas of the United States. Environmental Pollution,178, 229-236.

Padi, B. \& G.K. Owusu (1998). Towards an integrated pest management for sustainable cocoa production in Ghana. In: Proceedings of $1^{\text {st }}$ International Workshop on Sustainable Cocoa Growing, Panama City, Panama.

Pandey, S.; H. Singhand \& S.J. Singh (2013). Effect of environmental conditions on decomposition of eight woody species of a dry tropical forest. Plant Biosystems, 148, 1-10.

Post, W.M. \& K.C. Kwon (2000). Soil carbon sequestration and land-use change: rocesses and potential. Global Change Biology, 6, 317-27.

Rohr, T.; S. Manzoni; X. Feng; C.S.R. Menezes \& A. Porporato (2013). Effect of rainfall seasonality on carbon storage in typical dry ecosystem. JGR Biogeosciences, 118(3), 1156-1167.
Saj, S.; P. Jagoret \& H. Todem-Ngogue (2013). Carbon storage and density dynamics of associated trees in three contrasting Theobroma cacao agroforests of Central Cameroon. Agroforestry Systems, 87(6), 1309-1320.

Sommarriba, E.; C. Rolando; O. Luis; H.D. Miguel; E. Tania; M. Henry; A. Guadalupe; V. Estefany; A. Carlos; S. Eduardo \& D. Olivier (2013). Carbon stocks and cocoa yields in agroforestry systems of Central America. Agriculture, Ecosystems and Environment, 173, 46-57.

Torres, B.; O. Jadan; P. Aguirre; L. Hinojosa \& S. Gunter (2014). Contribution of traditional agroforestry to climate change adaptation in the ecuadorian Amazon: The Chakra system. p. 1-19. In: Handbook of Climate Change Adaptation (W.F. Leal, Eds). Springer Berlin Heidelberg.

UoU (2019). How trees affect the weather: Trees water-use strategies can intensify droughts. Science Daily. 24 June 2019.

Vaast, P. \& E. Sommarriba (2014). Trade-offs between crop intensification and ecosystem services; the role of agroforestry in cocoa cultivation. Agroforestry systems, 88(6), 947-956.

Vigneri, M. (2007). Drivers of cocoa production growth in Ghana. ODI Project Briefing, $1-4$.

Wade, A.S.I.; A. Asase; P. Hadley; J. Mason; K. Ofori-Frimpong; D. Preece; N. Spring $\&$ K. Norris (2010). Management strategies for maximizing carbon storage and tree species diversity in cocoa growing landscapes. Agriculture, Ecosystem, and Environment, 138, 324-34.

William R.L.; A.T. Anderegg; D.R. Trugman, D. R. Bowling; G. Salvucci \& S.E. Tuttle (2019). Plant functional traits and climate influence drought intensification and land atmosphere feedbacks. p. 1-6. In: Proceedings of the National Academy of Sciences. USA.

$* * 0 * *$ 